\title{
Introduction: the Microfoundations of Legal Intermediation in Organizational Contexts
}

\author{
Sebastian Billows \\ Postdoctoral fellow \\ Max Planck Institute for the Study of Societies (Germany) \\ billows@mpifg.de

\section{Lisa Buchter} \\ Graduate student \\ Northwestern University (USA) and Sciences Po (France) \\ lisabuchter2017@u.northwestern.edu

\section{Jérôme Pelisse} \\ Full professor \\ Sciences Po, Center for the Sociology of Organizations (CSO), CNRS, Paris, France \\ jerome.pelisse@sciencespo.fr
}

\section{Citation :}

Billows, S., Buchter, L. and Pélisse, J. (2019), "Introduction: The Microfoundations of Legal Intermediation in Organizational Contexts", Legal Intermediation (Studies in Law, Politics, and Society, Vol. 81), Emerald Publishing Limited, Bingley, pp. 1-9. https://doi.org/10.1108/S1059-433720190000081001

Keywords: legal intermediation, regulation, economy, labor, legal tools, neo-institutionalism, France

Law, public policy, and economic activity are intimately tied to each other. State policies and the legal system have often worked in favor of private economic interests. For instance, core features of the United States (US) legal system of the $19^{\text {th }}$ century were designed to protect the interests of the capitalist class (Horwitz 1992). Nowadays, narrow definitions of responsibility and privileged access to formal legal institutions still help the "haves" to “come out ahead" (Galanter 1974; 2013; Sutton 2001). Conversely, law has also been used (successfully or not) to coerce economic interests. Due to rules governing industrial relations and giving workers more power vis-à-vis their employers, corporations have become "legalized" settings (Selznick, 1969), where labor unions have gained leverage to shape workers' rights and accommodations (Chappe 2015; Dixon and Martin 2012; Guillaume, Pochic, and Silvera 2015; Pélisse 2007). 1 
Some laws mandated corporations to participate in broader societal change, such as the inclusion of discriminated minorities (Bereni and Revillard 2007; Burstein, Paul 1985; Dobbin 2009; Edelman 2016; Heyer et al. 2013; Lempert and Sanders 1986; Stryker and Pedriana 2004) or, in France, the fight against unemployment through the reduction of working time (Pélisse, 2004; 2011). Finally, the rise of the "regulatory state" (Thatcher 2014) or "regulatory capitalism" (Levi-Faur 2005) has led to even more interactions between law and economic activity. Despite popular belief that regulation was abandoned due to the diffusion of neoliberalism throughout the Western world in the 1980s, empirical evidence suggests that privatization, deregulation, and the promotion of market-based solutions under neoliberal governments expanded and extended business regulation in many national contexts (Braithwaite 2009; Vogel 1996) and even on a transnational basis (Bartley 2007, 2010). In other words, the alleged deregulation and move toward free markets led to a slow re-regulation of free markets in the form of soft regulation allegedly perfecting market performance (Levi-Faur 2005; Majone 1997).

A more and more prevalent phenomenon, the interplay between law, public policy, and economic activity has become a core part of socioeconomic and sociolegal scholarship (Stryker 2003; Edelman and Stryker 2005; Bessy, Delpeuch and Pélisse, 2011; Edelman, 2016). ${ }^{1}$ A major outcome of this literature is that public policy goals, legal norms, and the ensuing enforcement measures are inherently ambiguous (Dobbin 2009; Edelman 1992), especially as we shift from "government" to a "governance" model where multiple stakeholders design and implement regulations (Ansell and Gash 2008; Braithwaite 1982; Freeman and Minnow 2009; Kagan, Gunningham, and Thornton 2003). Due to normative ambiguity and to the organizational clout of economic interests (Perrow 1991), legal mandates always go through some degree of reinterpretation by economic and organizational actors, which impacts the reach of regulatory authorities (Edelman et al. 2011; Edelman 2016). Our argument is that this ongoing process of legal intermediation is shaped by a diverse set of actors and relies on hybrid tools and instruments, that have differential effects (either positive or negative) on

\footnotetext{
${ }^{1}$ While part of this literature describes the relation between law and economic activity as a top-down process, we focus our attention on the scholarship that views legal intermediation as a bottom-up process. The work on "regulatory capture" (Carpenter and Moss 2014) constitutes an example of the top-down approach. This perspective situates legal intermediation as a chain link between laws and regulation - which have to be applied to the economic world - and the economic and social relations embedded in organizations, as if law and economy or organizations were two separate spheres, of which we have to study the interrelations. A bottom-up approach does not only start from the social relations but is anchored in a constitutive perspective, where law and organizations are conceived together, shaping mutually one another through, notably, the activities of such legal intermediaries.
} 
organizational routines, compliance monitors, as well as judicial and legislative forces. The process leading from a new regulation to new organizational and business routines involves specific actors whom we call "legal intermediaries." While some economic actors and organizations turn to external and highly specialized corporate services, such as tax advisers or business lawyers, others rely on various types of "in-house" legal or non-legal specialists. A significant aspect of their work is to design specific devices, such as contracts, guidelines, or any other type of formalized procedures. Those legal devices, which stand halfway between the regulatory and the managerial sphere, shape the legal consciousness of laypeople who undertake economic activities or who work in large organizations (Ewick and Silbey 1998; Pélisse 2005).

Our processual, intra-organizational approach departs from other accounts of legal intermediation (Talesh and Pélisse, 2018). Regulation scholars are now taking "regulatory intermediation" seriously (Abbott, Levi-Faur, and Snidal 2017). However, because they focus on formal institutions such as international bodies or rating agencies, their approach overlooks subtler and more local forms of intermediation affecting organizations and economic activity. Despite using at times a different terminology, the neo-institutional literature on "legal environments" has already researched legal intermediation at length (Dobbin 2009; Edelman 2016; Talesh 2015). This literature's main findings can be summarized as follows: by infusing "managerial logics" into law, organizational fields are capable of mitigating the impact of legislation targeted at them. In a second step, which is referred to as "endogenization", managerialized law "subsequently influences understandings of law and legal actors and legal institutions" (Edelman 2016:19). Although we build on core insights of the neo-institutional approach, such as the managerialization of law and legal endogeneity, our approach to legal intermediation departs from the latter in four respects: (1) we challenge the current portrayal of legal intermediaries (primarily seen as legal experts or compliance professionals) by studying actors who are neither legal professionals nor corporate managers and who nonetheless deeply influence the interpretation of the law; (2) we emphasize the multiple roles of legal devices in shaping compliance or non-compliance; (3) from a methodological standpoint, we use an intraorganizational and intra-industry perspective rather than a field-based perspective; and (4) we investigate the relationship between law and economic activity within more varied social settings: in countries outside the United States and in other areas of regulation than antidiscrimination law, both of which are overwhelmingly represented in the neo-institutional literature.. 
Our first difference with the neo-institutional approach is that we provide a more detailed account of legal intermediaries' work and profile. Proponents of the neo-institutional approach have shown how different types of "compliance professionals" (Edelman 2016) reinterpreted US laws fighting employment discrimination. Compliance professionals include lawyers, consultants, human resource professionals, and insurance staff. By contrast, our symposium describes a wider range of legal intermediaries, such as legal counsels, civil rights activists, judicial experts salespeople, hospital directors, union members, managers, health and safety specialists, or even street level bureaucrats, who may or may not belong to established professions. In his contribution, Jérôme Pélisse presents a systematic comparison of these actors, which helps understanding and contrasting the different ways through which they contribute to legal intermediation. In particular, he stresses the importance of what he calls non-legal professionals acting as legal intermediaries within organizations. ${ }^{2}$ They contribute to the framing of ordinary legality on the workplace and in other areas of economic activity. Their contribution to legal intermediation depends on different types of constraints and resources, such as their relational profile, their hierarchical status or their local reputation.

Our second departure from the neo-institutional literature is our consideration of legal devices. Legal intermediaries design specific devices that shape economic activity and, in some cases, have feedback effects on regulation. Legal devices are a core feature of the neo-institutional approach to legal intermediation: in response to Equal Employment Opportunity law, organizations set up legal devices such as grievance procedures or guidelines which "symbolically demonstrate attention to law while maintaining sufficient flexibility to preserve managerial prerogatives that are seen as advancing business goals" (Edelman, 2016:31). However, we argue that the symbolic legitimacy of legal devices (Bourdieu 1987:4) is only one of three different ways in which they shape economic activity and regulatory outcomes. This symposium puts forth two other channels by which legal devices exercise their influence. The first is instrumental: the mere presence of rules means that economic actors can play with them (Lascoumes and Le Bourhis, 1996). The scholarship at the crossroads of social movement and organizations has showed how activists use symbolic devices put forth by companies to hold firms accountable for their pro-social claims and monitor their practices (McDonnell, King, and

\footnotetext{
2 This does not preclude us from analyzing borderline cases such as the French judicial expert, who stands in between laypeople and the legal profession, or the safety engineer working in a scientific institution, who must translate safety regulations into concrete rules readily usable by the scientists who conduct experiments.
} 
Soule 2015). The second effect of legal devices is constitutive. As Robin Stryker wrote, "law provides tools that help actors attribute meaning, existence, desirability or undesirability to their economic environment" (Stryker 2003:349). Weber provided empirical evidence of this a long time ago: from a historical standpoint, legal devices changed the way economic actors calculate economic returns and made strategic business decisions (Weber 1978). By shaping legal consciousness, legal devices may create new opportunities for certain disadvantaged groups to claim more rights (McCann 1994). To capture the diverse effects of legal devices on economic activity and organizations, we define the act of crafting objects such as contracts, guidelines, grievance procedures, collective agreements, or any other type of formalized procedures, as a social process. As Suchman has shown, such objects "possess both symbolic and technical properties" which arise from the interactions between experts and laypeople (Suchman 2003:91). Similar to Macaulay's work on contracts (1963), we adopt a "law in action" approach to find how and whether those objects are used in economic and organizational contexts. However, in contrast to Suchman and Macaulay's work, which tends to ignore institutional factors, we never lose sight of regulation and the institutionalized practices that might prevail at the level of an industry.

A third difference lies in the methods we use to study legal intermediaries and legal intermediation. Neo-institutional sociologists have collected evidence of legal intermediation by reading the professional literature (such as magazines), observing professional gatherings (such as conferences or "webinars"), and conducting statistical surveys about organizational practices across a large number of organizations. While these empirical strategies are useful to map out the diffusion of managerialized rules and procedures across the entire organizational field, it fails to account for how legal intermediaries craft and deliver advice within specific organizations and sectors. Yet, as most of the contributions in this special issue show, legal intermediation is particularly salient in the case of industry-specific regulation. To provide a much needed finer-grained view of legal intermediation, our contributions outline the "division of labor (...) in the cubicle" (Abbott 2005). Similar to the research conducted by Nelson and Nielsen (2000), for example, we investigate the daily interactions between laypeople and the legal intermediaries who assist them in complying with regulation. While the literature has insisted on how professional groups "frame" the law, we take into account both institutional factors and the informal micropolitics that give rise to local compromises between laypeople and legal intermediaries (Huising, 2015). The use of qualitative research methods enables us to capture not only the specific challenges faced by different actors, but also the impact of their 
status - formal and informal power, authority, position within the company, ability to speak out (Hirschman 1970) - on their ability to leverage social change. Additionally, this microsociological perspective helps us to explore cases where legal intermediation is a contentious issue. The neo-institutional literature tends to equate contentiousness with litigation (Revillard 2017). Our contributions show that even when litigation is absent, the internalization of law by organizations may turn into a contentious social process where different groups of actors defend conflicting interpretations of the law.

The last difference between our approach and previous neo-institutional research lies in the empirical scope of our investigations. While virtually all existing neo-institutional research is centered on US anti-discrimination $\mathrm{law}^{3}$, we expand the scope and the types of organizational environments where legal intermediation is analyzed, as Talesh and Pélisse (2018) did recently to find out how legal intermediaries impact social change. We believe that legal intermediation is virtually ubiquitous and holds true not only across countries, but also across types of organizations, whether it is private businesses, schools (Hallett 2010), hospitals (Kellogg 2009), or scientific laboratories (Huising and Silbey, 2013; Pélisse, 2017). Our contributions use this conceptual framework to address responses to different types of law. While Lisa Buchter's contribution addresses anti-discrimination law in the French context, the rest of our contributions describe areas of regulation that the literature has overlooked so far, such as financial rules, competition law, labor law, or health and safety procedures. Moreover, our contributions focus on European cases. This goes against some neo-institutional claims arguing that legal intermediation is unlikely outside the US. More specifically, we reject the claim that compared to the "weak" US federal state and its "vague" law, the "French legal system doesn't permit expansive reinterpretation" (Dobbin 2009:6-7). First, the alleged weakness of the US federal state and its legal system has been contested by political scientists, historians, and sociologists alike (Carpenter 2001, 2010; Lieberman 2015; Stryker and Pedriana 2004). Second, besides the contributions showcased in our symposium, there's already a wealth of empirical evidence showing how private actors reinterpret, managerialize, and endogenize the French legal environment (Bereni 2011; Billows 2016; Pélisse 2004; 2011).

Thanks to our approach that focuses on the contingent and processual aspects of legal intermediation, we find patterns of compliance that differ from those predicted by the existing

\footnotetext{
3 Talesh is among the few exceptions (Talesh, 2009, 2015).
} 
literature. In the neo-institutional approach, legal intermediation is a one-way street by which the profit-oriented logic of private business systematically taints the "legal logic," a sphere where "principles such as due process, equal access to law, and equal protection of law" dominate (Edelman 2016:23). Lauren Edelman claims that the "managerialization of the law" (or the infusion of the law with managerial ideals) is so prevalent that it led the US to become a "symbolic civil rights society" (Edelman 2016), while Frank Dobbin claims that diversity practices are adopted regardless of their efficacy, primarily to protect firms in courts (Dobbin 2009:209). We argue that this perspective on legal intermediation is too monolithic, and multiple case studies in this symposium corroborate this idea.

We find instances where legal intermediation actually succeeds in fulfilling the initial goals of regulation. Lisa Buchter's contribution, for instance, shows how activists co-opted French large corporations, and imposed an interpretation of anti-discrimination law that at times made a difference in the lives of the minorities whom legislation sought to protect. Camille Herlin and Alexis Spire show that professional intermediation of law does not always succeed in institutionalizing new interpretations of regulation and that the laypeople who buy their legal services sometimes contest their legitimacy. In her contribution on French hospitals, Fanny Vincent analyzes a contentious process of managerialization of labor law where nurses and hospital managers clash over a legal rule allowing 12-hour work shifts. Jérôme Pélisse's contribution addresses the diversity of legal intermediation in a systematic way by identifying the factors which allow legal intermediaries to influence legality and impact the legal consciousness of their audience. Their ability to do so depends on the legal frame and legal instruments that they can harness, the profile of the legal professionals and/or the laypeople with whom they interact, and their relative power in their organizations. Finally, our findings also reevaluate the role of the legal devices that organizations set up to comply with regulation and illustrate their diverse impact on legality and legal consciousness in organizations and in economic life. Sebastian Billows shows that, depending on the audience, a single legal device can bear many different meanings and shape different legalities within the same organizational context, a feature which gives large corporations more autonomy in interpreting how they should comply with regulation. Alina Surubaru goes even further and outlines the intraorganizational conflicts that arise from complex legal instruments such as contracts, which weakens their ability to constrain future business behavior.

\section{References}


Abbott, Andy. 2005. "Sociology of Work and Occupations." Pp. 307-330 in Handbook of Economic Sociology, edited by N. J. Smelser and R. Swedberg. Princeton: Princeton University Press.

Abbott, Kenneth, David Levi-Faur, and Duncan Snidal. 2017. "Theorizing Regulatory Intermediaries: The RIT Model." The Annals of the American Academy of Political and Social Science 670(1):13-35.

Ansell, C. and A. Gash. 2008. "Collaborative Governance in Theory and Practice." Journal of Public Administration Research and Theory 18(4):543-71.

Bartley, Tim. 2007. "Institutional Emergence in an Era of Globalization: The Rise of Transnational Private Regulation of Labor and Environmental Conditions." American Journal of Sociology 113(2):297-351.

Bartley, Tim. 2010. "Transnational Private Regulation in Practice: The Limits of Forest and Labor Standards Certification in Indonesia.” Business and Politics.

Bereni, Laure. 2011. "Le Discours de la Diversité en Entreprise : Genèse et Appropriations." Sociologies pratiques (23):9-19.

Bereni, Laure and Anne Revillard. 2007. "Des Quotas à la Parité : «Féminisme d'État » et Représentation Politique (1974-2007).” Genèses (67):5-23.

Billows, Sebastian. 2016. “La Politique de l'ambiguïté Juridique. Quand 1'Etat Tente de Réguler Les Échanges Entre La Grande Distribution et Ses Fournisseurs.” Sociologie Du Travail 58(1):8-31.

Bourdieu, Pierre. 1987. "The Force of Law : Toward a Sociology of the Juridical Field." The Hastings Law Journal 38(1971):805-853.

Braithwaite, John. 1982. "Enforced Self-Regulation: A New Strategy for Corporate Crime Control." Michigan Law Review 80:1466-1507.

Braithwaite, John. 2009. Regulatory Capitalism: How It Works, Ideas for Making It Work Better. London: Edward Elgar Publishing.

Burstein, Paul. 1985. Discrimination, Jobs, and Politics: The Struggle for Equal Opportunity in the United States Since the New Deal. Chicago: University of Chicago Press.

Carpenter, Daniel. 2010. Reputation and Power: Organizational Image and Pharmaceutical Regulation at the FDA. Princeton: Princeton University Press.

Carpenter, Daniel and David A. Moss. 2014. Preventing Regulatory Capture: Special Interest Influence and How to Limit It. New York and Cambridge.

Carpenter, Daniel P. 2001. The Forging of Bureaucratic Autonomy: Reputations, Networks, and Policy Innovation in Executive Agencies, 1862-1928. Princeton: Princeton University Press.

Chappe, Vincent-Arnaud. 2015. "Les discriminations syndicales saisies par le droit à PSA." La nouvelle revue du travail (7). 
Dixon, Marc and Andrew W. Martin. 2012. "We Can't Win This on Our Own: Unions, Firms, and Mobilization of External Allies in Labor Disputes." American Sociological Review 77(6):946-69.

Dobbin, Frank. 2009. Inventing Equal Opportunity. Princeton: Princeton University Press.

Edelman, Lauren B. 1992. "Legal Ambiguity and Symbolic Structures : Organizational Mediation of Civil Rights Lawl.” American Journal of Sociology 97(6):1531-1576.

Edelman, Lauren. 2016. Working Law: Courts, Corporations, and Symbolic Civil Rights. Chicago and London: The University of Chicago Press.

Edelman, Lauren B. and Robin Stryker. 2005. "A Sociological Approach to Law and the Economy." Pp. 527-551 in The Handbook of Economic Sociology. Princeton: Princeton University Press.

Edelman, Lauren B., Linda H. Krieger, Scott R. Eliason, Catherine R. Albiston, and Virginia Mellema. 2011. "When Organizations Rule: Judicial Deference to Institutionalized Employment Structures.” American Journal of Sociology 117(3):888-954.

Ewick, Patricia and Susan Silbey. 1998. The Commonplace of Law: Stories from Everyday Life. University of Chicago Press. Chicago.

Freeman, J. and M. Minnow. 2009. Government by Contract: Outsourcing and American Democracy. Cambridge, Massachusetts: Harvard University Press.

Galanter, Marc. 1974. "Why The " Haves " Come Out Ahead : Speculations On The Limits Of Legal Change." Law \& Society Review 9(1):95-160.

Guillaume, Cécile, Sophie Pochic, and Rachel Silvera. 2015. "Dans Les Syndicats: Du Volontarisme à La Contrainte Légale.” Travail, Genre et Sociétés 34(2):193-98.

Hallett, Tim. 2010. “The Myth Incarnate: Recoupling Processes, Turmoil, and Inhabited Institutions in an Urban Elementary School.” American Sociological Review 75(1):5274.

Heyer, Katharina, Pierre-Yves Baudot, Céline Borelle, and Anne Revillard. 2013. "Droits Ou Quotas ? L' American with Disabilities Act (ADA) Comme Modèle Des Droits Des Personnes Handicapées." Terrains \& Travaux 23(2):127.

Hirschman, A. O. 1970. Exit, Voice and Loyalty. Responses to Decline in Firms, Organizations and States. Harvard University Press. Cambridge, MA.

Horwitz, Morton. 1992. The Transformation of American Law: The Crisis of Legal Orthodoxy. Oxford, New York: Oxford University Press.

Huising, R., Silbey S. 2011. "Governing the gap: Forging safe science through relational regulation.", Regulation and Governance (1), 14-42.

Huising, R., Silbey S. 2013. "Constructing Consequences for Noncompliance: The Case of Academic Laboratories." Annals of the American Academy of Political and Social Science, vol. 649: 157-177. 
Huising, R., Silbey S. 2016. "27. Surveillance and Regulation of Laboratory Practices." pp.798-848 in The Handbook of Science and Technology Studies, edited by U. Felt, R. Fouché, C.A. Miller and L. Smith-Doerr, Cambridge and London, MIT Press.

Huising, R. 2015, "To Hive or to Hold? Producing Professional Authority through Scut Work", Administrative Science Quarterly 60 (2): 263-299.

Kagan, R., N. Gunningham, and D. Thornton. 2003. "Explaining Corporate Environmental Performance: How Does Regulation Matter." Law \& Society Review 37(1):51-90.

Kellogg, Katherine. 2009. "Operating Room: Relational Spaces and Microinstitutional Change in Surgery.” American Journal of Sociology 115(3):657-711.

Lascoumes, Pierre and Jean-Pierre Le Bourhis. 1996. "Des 'Passe-Droits' Aux Passes Du Droit. La Mise En Oeuvre Socio-Juridique de l'action Publique.” Droit et Société 32(1):51-73.

Lempert, Richard and Joseph Sanders. 1986. An Invitation to Law and Social Science: Deserts, Disputes and Distribution. Philadelphia: University of Pennsylvania Press.

Levi-Faur, David. 2005. "The Global Diffusion of Regulatory Capitalism." The Annals of the American Academy of Political and Social Science 598(1):12-32.

Lieberman, Robert C. 2015. "Private Power and American Bureaucracy: The State, the EEOC, and Civil Rights Enforcement." Pp. 259-286 in Boundaries of the State in US History, edited by J. T. Sparrow, W. J. Novak, and S. W. Sawyer. Chicago and London: The University of Chicago Press.

Macaulay, S. 1963. "Non-Contractual Relations in Business.” American Journal of Sociology 28(1). Retrieved (http://scholar.google.com/scholar?hl=en\&btnG=Search\&q=intitle:non+contractual+r elations+in+business\#2)

Majone, G. 1997. "From the Positive to the Regulatory State: Causes and Consequences of Changes in the Mode of Governance." Journal of Public Policy 17(02):139-167.

McCann, Michael. 1994. Rights at Work. Pay Equity Reform and the Politics of Legal Mobilization. The University of Chicago Press.

McDonnell, Mary-Hunter, Brayden G. King, and Sarah A. Soule. 2015. "A Dynamic Process Model of Private Politics: Activist Targeting and Corporate Receptivity to Social Challenges." American Sociological Review 80(3):654-78.

Nelson, Robert L. and Laura Beth Nielsen. 2000. "Cops, Counsel, and Entrepreneurs: Constructing the Role of Inside Counsel in Large Corporations." Law \& Society Review 34(2):457-494.

Pélisse, Jérôme. 2004. A la recherche du temps gagné. Sens et usages sociaux des règles autour des 35h, Thèse de sociologie, Centre d'Etudes de l'Emploi, Université Marne la Vallée, 668p. 
Pélisse, Jérôme. 2005. "A-t-on conscience du droit? Autour des Legal Consciousness Studies, Summary." Genèses no 59(2):114-30.

Pélisse, Jérôme. 2007. “7. Les Usages Syndicaux du Droit et de la Justice.” Pp. 165-89 in La fonction politique de la justice, Recherches/Territoires du politique. Paris: La Découverte.

Pélisse, Jérôme. 2009. "Judiciarisation Ou Juridicisation? Usages et Réappropriations Du Droit Dans Les Conflits Du Travail.” Politix (86):73-96.

Pélisse, Jérôme. 2011. “La Mise En OEuvre Des 35 Heures : D’une Managérialisation Du Droit à Une Internalisation de La Fonction de Justice.” Droit et Société (77):39-65.

Pélisse, Jérôme. 2017. «Gérer les risques par le droit : articulation et intermédiation dans les laboratoires de nanosciences en France et aux Etats-Unis ». Droit et société 96 (2) : 321-336.

Perrow, Charles. 1991. “A Society of Organizations.” Theory and Society 20(6):725-62.

Revillard, Anne. 2017. "Social Movements and the Politics of Bureaucratic Rights Enforcement: Insights from the Allocation of Disability Rights in France." Law \& Social Inquiry 42(2):450.

Silbey, S., Agrawal R., 2011. «The Illusion of Accountability: Information Management and Organizational Culture », Droit et société 77: 69-86

Stryker, R. 2003. "Mind the Gap: Law, Institutional Analysis and Socioeconomics." SocioEconomic Review 1(3):335-367.

Stryker, Robin and Nicholas Pedriana. 2004. "The Strength of a Weak Agency : Enforcement of Title VII of the 1964 Civil Rights Act and the Expansion of State Capacity, 19651971.” American Journal of Sociology 110(3):709-760.

Suchman, Mark C. 2003. "The Contract as Social Artifact." Law and Society Review 37(1):91-142.

Sutton, John. 2001. Law/Society: Origins, Interactions, and Change. Sage.

Talesh, Shauhin. 2009. “The Privatiszation of Public Legal Rights: How Manufactures Construct the Meaning of Consumer Law". Law \& Society Rev. 43: 527-562.

Talesh, Shauhin. 2015. "Legal Intermediaries: How Insurance Companies Construct the Meaning of Compliance with Antidiscrimination Laws." Law \& Policy 37(3):209-239.

Talesh, Shauhin and Pélisse, Jérôme. 2018. " How Legal Intermediaries Facilitate or Inhibit Social Change". LIEPP Working Paper $\mathrm{n}^{\circ} 73$.

Thatcher, Mark. 2014. "From Old to New Industrial Policy via Economic Regulation." Rivista Della Regolazione Dei Mercati (2):6-22.

Vogel, Steven Kent. 1996. Freer Markets, More Rules: Regulatory Reform in Advanced Industrial Countries. Cornell: Cornell University Press. 
Weber, Max. 1978. Economy and Society. edited by G. Roeth and C. Wittich. Berkeley: University of California Press. 